\title{
Management of Late Blight [Phytophthora Infestans (Mont.) De Bary] of Potato in Central Ethiopia
}

\author{
Adina Getinet*, Mashilla Dejene (PhD), Dr. Bekele Kassa (PhD), Dr. Wassu Mohammed (PhD) \\ Ethiopia
}

*Corresponding Author: Adina Getinet, Ethiopia

\begin{abstract}
The experiment was conducted at Holetta Agricultural Research Center and on-farm at Tikur Enchini during the 2017 main season to assess efficacy of alternate fungicides application and potato varieties on late blight epidemics. Treatments were factorial arranged in a randomized complete block design with three replications. Analysis was performed combined for the two locations due to homogeneous error variances. Combined analysis of variance indicated that effect of varieties, fungicide, locations and their interactions significantly reduced Late blight epidemic parameters and enhanced yield. The lowest mean AUDPC values (168, 291.15 and 456.5-\%unit-days) were recorded on plots sprayed with Trust-Cymocop 439.5 WP + Ridomil Gold MZ 68 WG + Mancozeb 80 WP (TRM) spray sequence on the varieties Belete, Gudenie and Jalenie, respectively. High disease epidemics (AUDPC values of 1135.35, 963.35 and 1965.85\%unit-days) occurred on unsprayed plots of the varieties Belete, Gudenie and Jalenie, respectively. Alternate fungicide application with TRM spray sequence reduced late blight severity up to $75 \%, 60.84 \%$ and $68.33 \%$ on the varieties Belete, Gudenie and Jalenie, respectively, compared to the control. The overall results revealed that alternate fungicide application with TRM spray sequence are found effective to slow down potato late blight epidemics and improve potato productivity; and thus, recommended for the study areas along with other crop management practices.
\end{abstract}

Keywords: Area under disease progress curve (AUDPC), disease progress rate, Phytophthora infestans, potato, severity.

\section{INTRODUCTION}

Potato (Solanum tuberosum L.) is one of the most important food crops worldwide. It ranks third after rice and wheat for human consumption [1]. Annual world production of potato is about 330 million tons harvested from 18,651,838 ha and, in Africa, the total production is about 17,625,680 t from a total cultivated area of 1,765,617 ha [2]. In Ethiopia, total cultivated area of potato is 70,131.32 ha from which 943,233.44 tons is harvested [3]. The national average tuber yield is lower than the world average yield. The national average potato tuber yield on farmers' fields in Ethiopia is also only $13.4 \mathrm{t}$ $\mathrm{ha}^{-1}$, which is much lower than $38 \mathrm{t} \mathrm{ha}^{-1}$ reported from experimental plots [1].

There are many factors contributing to low yield of potato in Ethiopia, of which late blight [Phytophthora infestans] is the major disease that cause yield loss up to $100 \%$ [4]. In Ethiopia, it has been reported that late blight is a major limitation to potato production in high humid elevations; with estimate average yield losses of about $30-75 \%$ on susceptible varieties [5].

Late blight is a polycyclic disease, having several cycles of infection and inoculum production during one growing season [6]. The polycyclic nature of the pathogen forced the potato growers to apply fungicides many times in one growing season. Spray of fungicides up to 15-20 times per growing season was reported depending on the climatic conditions and intensity of the potato cultivation, to protect the crop against late blight [7]. However, repeated application of fungicides slow disease suppression activity due to a gradual loss of sensitivity of the targeted pathogen population to the fungicide in addition to the increase in production costs and environmental risk. For instance, resistance to Ridomil or metalaxyl appeared in 1980, within a few years after its introduction, and led to control failures in Ireland and the Netherlands [8]. Past studies have revealed that the occurrence of Ridomil or metalaxyl resistance in $P$. infestans populations is associated with severe late blight epidemics, genetic diversity and pathogen resurgence [9]. Hence, it is important and imperative to rotate fungicides with various modes of action on weekly or bi-weekly bases to reduce the risk of 
resistance development and increase the effectiveness of fungicides . Therefore, the objective of this study was to investigate efficacy of alternate fungicides application and potato varieties on late blight epidemic development in potato production areas of centeral Ethiopia.

\section{MATERIALS AND MeTHODS}

\subsection{Description of the Study Areas}

The experiment was conducted under rain- fed conditions at Holetta Agricultural Research Center and at Tikur Enchini on farm in Central Ethiopia during the 2017 main cropping season. Holetta Agricultural Research Center is located at $9^{\circ} 00^{\prime} \mathrm{N}, 38^{\circ} 30^{\prime} \mathrm{E}$ at an altitude of 2400 meters above sea level (m.a.s.l.). Tikure Enchini is located at $8.84^{\circ} 00^{\prime} \mathrm{N}, 39.67^{\circ} 30^{\prime} \mathrm{E}$ at an altitude of 2477 (m.a.s.l.).

\subsection{Experimental Materials and Procedures}

Three potato varieties (Belete, Gudanie and Jalenie) recommended by Holetta Agricultural Research Center for cultivation in the central highlands and similar agro-ecologies in other parts of Ethiopia were used for the experiment. The varieties Belete, Gudanie and Jalenie (Table 1) are selected as resistant, moderately resistant and susceptible to late blight [10]. Three fungicides including the systemic Ridomil Gold MZ 68 WG, (Metalaxyl - 4\% + Mancozeb - 64\%), Trust-Cymocop 439.5 WP (Cymoxanil $42 \mathrm{~g} \mathrm{~kg}^{-1}+$ Copper oxychloride $397 \mathrm{~g} \mathrm{~kg}^{-1}$ ) and contact fungicide Mancozeb $80 \mathrm{WP}$, which were recommended for late blight control, were used as treatments. Fungicides application was started as soon as the disease symptom was observed on the field.

Table1. Description of potato varieties used for the field experiment

\begin{tabular}{|c|c|c|c|c|c|}
\hline \multirow{2}{*}{$\begin{array}{c}\text { Name of } \\
\text { Variety }\end{array}$} & Accession Code & Year of release & \multirow{2}{*}{$\begin{array}{c}\text { Altitude } \\
\text { (m.a.s.1.) }\end{array}$} & \multicolumn{2}{|c|}{ Tuber yield (t ha ${ }^{-1}$ ) } \\
\cline { 4 - 6 } & Besearch Field & Farmer's Field \\
\hline Belete & CIP-393371.58 & 2009 & $1600-2800$ & 47.2 & $28.0-33.8$ \\
\hline Gudanie & CIP-386423.13 & 2006 & $1600-2800$ & 29.0 & 21.0 \\
\hline Jalenie & CIP-37792-5 & 2002 & $1600-2800$ & 40.3 & 29.1 \\
\hline
\end{tabular}

Source: [11]

\subsection{Treatments and Experimental Design}

A total of 21 treatments arranged in a factorial experiment using three potato varieties in combination with three fungicide sprays alternating with one another at each spray sequence and three sole fungicide application sequences (six fungicides alternate and sole fungicide application sequence and control). Therefore, there were two factors, viz. potato varieties and fungicide sprays alternating with one another at each spray sequence and also spraying individually each fungicide at all intervals for each variety. The treatments were arranged in a randomized complete block design (RCBD) with three replications.

The treatment combinations include the following:

1. Belete+Control (no fungicide application)

2. Belete+Ridomil + Mancozeb + Trust-Cymocop

3. Belete +Trust cymocop + Ridomil + Mancozeb

4. Belete + Mancozeb + Trust Cymocop + Ridomi

5. Belete + Mancozeb + Mancozeb + Mancozeb

6. Belete + Trust Cymocop + Trust Cymocop + Trust Cymocop

7. Belete + Ridomil + Ridomil + Ridomil

8. Gudenie+Control (no fungicide application)

9. Gudenie +Ridomil + Mancozeb + Trust-Cymocop

10. Gudenie + Trust cymocop + Ridomil + Mancozeb

11. Gudenie +Mancozeb + Trust Cymocop + Ridomi

12. Gudenie +Mancozeb + Mancozeb + Mancozeb

13. Gudenie + Trust Cymocop + Trust Cymocop + Trust Cymocop

14. Gudenie +Ridomil + Ridomil + Ridomil

15. Jalenie+Control (no fungicide application) 
16. Jalenie + Ridomil + Mancozeb + Trust-Cymocop

17. Jalenie + Trust cymocop + Ridomil + Mancozeb

18. Jalenie + Mancozeb + Trust Cymocop + Ridomi

19. Jalenie +Mancozeb + Mancozeb + Mancozeb

20. Jalenie + Trust Cymocop + Trust Cymocop + Trust Cymocop

21. Jalenie +Ridomil + Ridomil + Ridomil

\subsection{Experimental Field Management}

The gross plot size was $3 \times 3 \mathrm{~m}=9 \mathrm{~m}^{2}$, which accommodated 10 plants per row and thus 40 plants per plot. Medium-sized and well-sprouted potato tubers of three selected potato varieties were planted on prepared ridges of four rows per plot at spacing of $75 \mathrm{~cm}$ between rows and $30 \mathrm{~cm}$ between plants. The spacing between plots and adjacent replications was $1 \mathrm{~m}$ and $2 \mathrm{~m}$, respectively. Fungicide application was started when disease symptoms appeared in the field. Subsequent spray was made at 7 and 14 days' interval for the contact (Mancozeb) and systemic (Ridomil Gold MZ 68 WG, and TrustCymocop 439.5 WP) fungicides, respectively. The plots were managed properly as per the package recommendation for potato production.

\subsection{Disease Assessment}

Disease assessment began on 31 and 35 days after planting at Holetta and Tikur Enchini, respectively, when the disease symptom was observed on the field and continued every seven days until senescence. Disease incidence was recorded by counting plants with disease symptom to the total plant population in the central two rows. Disease severity was assessed based on percent leaf area infected by using Key for assessing severity of late blight under field conditions [12]. Area under disease progress curve (AUDPC) was calculated for each plot using the formula developed by [13].

$A U D P C=\sum_{n i=1}^{n-1}\left(\left[0.5\left(x_{i+1}+x_{i}\right)\left(t_{i+1}-t_{i}\right)\right]\right.$

Where $\mathrm{Xi}$ is the cumulative disease severity expressed as a proportion at the $\mathrm{i}^{\text {th }}$ observation, $\mathrm{t}_{\mathrm{i}}$ is the time (days after planting) at the $\mathrm{i}^{\text {th }}$ observation and $\mathrm{n}$ is the total number of observations.

\subsection{Data Analysis}

Analysis of variance (ANOVA) was performed for disease incidence, disease severity and AUDPC to determine the effect of treatments and their interactions. [14]. Analysis was performed combined for the two locations due to homogeneous error variances. The data analyses were done using the Statistical Analysis System (SAS) Version 9. Least significant difference (LSD at 5\% probability level) was used for mean separation. Relationship of final SI and AUDPC with yield and yield components were examined using correlation analysis. Logistic, $\ln [(\mathrm{Y} / 1$ - Y)], [15] and Gompertz, $\ln [-\ln (\mathrm{Y})][16]$ models were compared for estimation of disease progression from each treatment. The goodness of fit of the models was tested based on the magnitude of the coefficient of determination (R2) and residuals (SE) obtained using each model [17]. As a result, there was higher coefficient of determination (R2) and lower standard error (SE) from logistic than from Gompertz model. Data had better fit to logistic than Gompertz model. Therefore, rate of increase in bacterial wilt was estimated and compared using the logistic model.

\section{RESULTS AND DISCUSSION}

\subsection{Disease Incidence}

The combined analysis of disease incidence had highly significant differences $(\mathrm{P} \leq 0.001)$ among potato varieties, fungicide, locations and their interactions (data not shown). The highest disease incidence (98.33 and 78.33\%) were showed on the variety Belete sprayed with TTT and MMM, spray sequence respectively, while the lowest disease incidence (14.14 and 18.34\%) showed on Belete variety sprayed with RRR and TRM spray sequence, respectively. TRM and RRR spray sequence did not significantly differ from each other with respect to mean disease incidence reduction; however, both spray sequences significantly $(\mathrm{p} \leq 0.05)$ reduced mean disease incidence as compared to the unsprayed plot. On Gudenie variety the lowest (14.17\%) mean disease incidence was showed on when the variety sprayed with TRM spray sequence, while the highest mean disease incidence (80\%) was recorded on variety Gudenie sprayed with TTT spray sequence. On variety Jalenie the lowest 
(17.5\%) mean disease incidence was obtained on when the variety sprayed with RRR spray sequence. The second lowest $(41.67 \%)$ mean disease incidence also showed on the variety sprayed with TRM spray sequence and significantly reduced mean disease incidence as compared to the unsprayed plots. While the highest mean disease incidence (100\%) was recorded on plots sprayed with TTT spray sequence which was not differ from the unsprayed plot (Table 2). Thus alternate fungicide application with TRM spray sequence effectively reduced mean disease incidence in all tested varieties.

\subsection{Disease Severity}

The combined analysis of disease severity showed highly significant differences $(\mathrm{P} \leq 0.001)$ among interactions effects of the three potato varieties, fungicide application sequence and locations (data not shown). On Belete variety the lowest (8.34 and 14.17\%) mean disease severity exhibited on plots sprayed with RRR and TRM spray sequence respectively, while the highest disease severity (81.67\%) was exhibited on plots sprayed with TTT spray sequence. TRM and RRR spray sequence on this variety did not significantly differ from each other with respect to mean disease severity reduction; however, both fungicide spray sequence significantly reduced mean disease severity as compared to the unsprayed plot. All fungicide spray sequence on Gudenie potato variety significantly $(\mathrm{p} \leq 0.05)$ reduced mean disease severity as compared to unsprayed plots. On variety Jalenie the lowest (10\% and 15\%) disease severity showed on plots sprayed with RRR and TRM spray sequence, respectively, while the highest disease severity $(75 \%)$ showed on the plots sprayed with TTT spray sequence. TRM and RRR spray sequence did not significantly differ from each other with respect to mean disease severity reduction, however, both fungicide spray sequence reduced mean disease severity as compared with the unsprayed plot. Thus, alternate fungicide application with TRM spray sequence effectively reduced mean disease severity on all tested varieties. The current finding is consistent with the observation of [18] who reported that using the systemic fungicide Ridomil alone and Ridomil and Mancozeb applied sequentially was more effective in lowering severity of late blight than the sole use of the protectant fungicide Mancozeb.

\subsection{Area under Disease Progress Curve (AUDPC)}

The combined analysis of area under disease progress curve (AUDPC) value showed highly significant differences $(\mathrm{P} \leq 0.001)$ among interactions effects of the three potato varieties, fungicide application sequence and locations (data not shown). On variety Belete the lowest AUDPC values (150.4, 151.3 and 168 -\% unit-days) showed on plots sprayed with RRR, RMT and TRM spray sequence, respectively, while the highest AUDPC value (820-\% unit-days) showed from plots sprayed with TTT spray sequence. TRM, RMT and RRR spray sequence did not significantly differ from each other with respect to mean AUDPC value reduction however, all the three fungicide spray sequences significantly reduced mean AUDPC value as compared to unsprayed plots. Thus alternate fungicide application with TRM spray sequence on Belete potato variety effectively reduced mean AUDPC values.

On variety Gudenie all spray sequences did not significantly differ from each other with respect to mean AUDPC value reduction however, all fungicide spray sequences significantly reduced mean AUDPC value as compared to unsprayed plots. Thus alternate fungicide application with TRM spray sequence on the variety Gudenie effectively reduced mean AUDPC values.

On variety Jalenie the highest mean AUDPC value reduction showed on plots sprayed with RRR and TRM, spray sequence which did not significantly differ from each other with respect to mean AUDPC value reduction, however, both fungicide spray sequence significantly reduced mean AUDPC value as compared to the variety sprayed with other spray sequence and unsprayed plots. Thus alternate fungicide application with TRM spray sequence effectively reduced mean AUDPC value.

Table2. Interaction effect of alternate fungicide application and potato varieties on late blight incidence severity and area under disease progress curve

\begin{tabular}{|c|c|c|c|c|}
\hline Varieties & Fungicide & Incidence (\%) & Severity (\%) & AUDPC (-\% unit-days) \\
\hline \multirow{4}{*}{ Belete } & Unsprayed & $100^{\mathrm{a}}$ & $89.17^{\mathrm{a}}$ & $1135.5^{\mathrm{bc}}$ \\
\cline { 2 - 5 } & RMT & $33.33^{\text {ef }}$ & $17.50^{\text {gh }}$ & $151.25^{\mathrm{i}}$ \\
\cline { 2 - 5 } & TRM & $18.33^{\text {gh }}$ & $14.17^{\text {ghi }}$ & $168^{\mathrm{i}}$ \\
\cline { 2 - 5 } & MTR & $48.33^{\mathrm{d}}$ & $20.00^{\text {fg }}$ & $306.58^{\text {ghi }}$ \\
\cline { 2 - 5 } & MMM & $78.33^{\mathrm{b}}$ & $40.83^{\mathrm{d}}$ & $455^{\text {fg }}$ \\
\cline { 2 - 5 } & TTT & $98.33^{\mathrm{a}}$ & $81.67^{\mathrm{ab}}$ & $820.67^{\mathrm{de}}$ \\
\cline { 2 - 5 } & RRR & $14.17^{\mathrm{h}}$ & $8.33^{\mathrm{i}}$ & $150.42^{\mathrm{i}}$ \\
\hline
\end{tabular}




\begin{tabular}{|c|c|c|c|c|}
\hline \multirow[t]{7}{*}{ Gudenie } & Unsprayed & $93.33^{\mathrm{a}}$ & $71.67^{\mathrm{c}}$ & $963.33^{\mathrm{cd}}$ \\
\hline & RMT & $18.33^{\text {gh }}$ & $12.50^{\text {ghi }}$ & $273.58^{\mathrm{hi}}$ \\
\hline & TRM & $14.17^{\mathrm{h}}$ & $10.83^{\mathrm{hi}}$ & $291.17^{\text {ghi }}$ \\
\hline & MTR & $25.00^{\mathrm{fg}}$ & $15.83^{\text {ghi }}$ & $316.42^{\text {ghi }}$ \\
\hline & MMM & $48.33^{\mathrm{d}}$ & $10.00^{\text {hi }}$ & $291.75^{\mathrm{ghi}}$ \\
\hline & TTT & $80.00^{\mathrm{b}}$ & $29.17^{\mathrm{e}}$ & $503.08^{\mathrm{f}}$ \\
\hline & RRR & $20.83^{\text {gh }}$ & $11.67^{\mathrm{hi}}$ & $263.17^{\mathrm{hi}}$ \\
\hline \multirow[t]{7}{*}{ Jalenie } & Unsprayed & $100.00^{\mathrm{a}}$ & $83.33^{\mathrm{a}}$ & $1965.83^{\mathrm{a}}$ \\
\hline & RMT & $66.67 \mathrm{c}$ & $26.67^{\mathrm{ef}}$ & $685.33^{\mathrm{e}}$ \\
\hline & TRM & $41.67^{\mathrm{de}}$ & $15.00^{\text {ghi }}$ & $456.67^{\mathrm{fg}}$ \\
\hline & MTR & $71.67^{\mathrm{bc}}$ & $34.17^{\text {de }}$ & $734.5^{\mathrm{e}}$ \\
\hline & MMM & $75.00^{\mathrm{bc}}$ & $34.17^{\text {de }}$ & $699.58^{\mathrm{e}}$ \\
\hline & TTT & $100.00^{\mathrm{a}}$ & $75.00^{\mathrm{bc}}$ & $1277.92^{b}$ \\
\hline & RRR & $17.50^{\mathrm{gh}}$ & $10.00^{\mathrm{hi}}$ & $361.25^{\text {fgh }}$ \\
\hline LSD (0.05) & & 10.61 & 7.76 & 174.4 \\
\hline
\end{tabular}

Means within the same column followed by the same letter(s) are not significantly different, LSD $(0.05)=$ Least significant difference at $\mathrm{P} \leq 0.05, \mathrm{M}=$ Mancozeb $80 \mathrm{WP}, \mathrm{R}=$ Ridomil Gold MZ $68 \mathrm{WG}, \mathrm{T}=$ Trust-Cymocop 439.5 WP applied with the indicated sequence in the three successive sprays

\subsection{Disease Progress Rate}

On variety Belete, the lowest $(0.03,0.06$, and 0.07 units per day) progress rate showed on plots sprayed with RRR, RMT and TRM spray sequence; while the highest ( 0.2 units per day) progress rate showed on plots sprayed with TTT spray sequence and unsprayed plots at Holetta (Table 3). At Tikur Enchini the lowest ( 0.0455 units per day) progress rate was recorded on plots sprayed with TRM spray sequence; while the highest ( 0.142 units per day) progress rate was recorded on the variety unsprayed plots (Table 4). Thus at both locations alternate fungicide application with TRM spray sequence showed the lowest disease progress rate on the variety Belete.

On the variety Gudenie The lowest (0.0271 and 0.0434 units per days) progress rate showed on plots sprayed with MMM and TRM spray sequence, respectively, while the highest (0.181units per day) progress rate was showed on unsprayed plots of the variety at Holetta (Table 3). At Tikur Enchini the lowest ( 0.00424 units per day) progress rate was showed on plots sprayed with TRM spray sequence; while the highest ( 0.0613 units per day) progress rate was showed on the variety unsprayed plots. Thus at both locations alternate fungicide application with TRM spray sequence showed the lowest disease progress rate on the variety Gudenie.

On the variety Jalenie the lowest (0.0083 and 0.0201units per day) progress rate showed on plots sprayed with RRR and TRM spray sequences, respectively; while the highest $(0.179$ and 0.157 units per day) progress rate showed on the variety sprayed with TTT spray sequence and unsprayed plots at Holetta (Table 3). At Tikur Enchini the lowest (0.00863 and 0.0107 units per day) progress rate showed on the variety sprayed with RRR and TRM spray sequence, respectively, while the highest (0.067units per day) progress rate showed on the variety unsprayed plots (Table 4). Thus at both locations alternate fungicide application with TRM spray sequence showed the lowest disease progress rate on the variety Jalenie.

Table3. The effect of alternate fungicide application and potato varieties on late blight progres rate at Holetta in 2017 season

\begin{tabular}{|c|c|c|c|c|c|c|c|}
\hline Varieties & $\begin{array}{c}\text { Fungicide spray } \\
\text { Sequence }\end{array}$ & DSi & DSf & $\begin{array}{c}\text { Rate } \\
\text { units/day }\end{array}$ & $\begin{array}{c}\text { SE of } \\
\text { intercept }\end{array}$ & $\begin{array}{c}\text { SE of } \\
\text { constant }\end{array}$ & R2 \\
\hline \multirow{4}{*}{ Belete } & Unsprayed & 9.00 & 99 & 0.224 & -14.8 & 1.982 & 81.3 \\
\cline { 2 - 8 } & RMT & 2.00 & 10 & 0.0589 & -7.23 & 0.5766 & 78 \\
\cline { 2 - 8 } & TRM & 3.00 & 20 & 0.0708 & -7.61 & 1.052 & 60.6 \\
\cline { 2 - 8 } & MTR & 2.00 & 20 & 0.0942 & -8.53 & 0.8107 & 80.7 \\
\cline { 2 - 8 } & MMM & 2.00 & 35 & 0.114 & -9.66 & 0.8077 & 87 \\
\cline { 2 - 8 } & TTT & 2.00 & 92.66 & 0.227 & -15.8 & 1.985 & 81.6 \\
\cline { 2 - 8 } & RRR & 3.00 & 6.66 & 0.0326 & -5.27 & 1.073 & 23.9 \\
\hline & Unsprayed & 11.67 & 96 & 0.181 & -12 & 1.933 & 74.8 \\
\hline
\end{tabular}

International Journal of Research Studies in Agricultural Sciences (IJRSAS) 


\begin{tabular}{|c|c|c|c|c|c|c|c|}
\hline \multirow{6}{*}{ Gudenie } & RMT & 3.00 & 16.67 & 0.0608 & -6.85 & 0.9433 & 58.5 \\
\hline & TRM & 4.33 & 15 & 0.0434 & -5.43 & 0.5636 & 66.8 \\
\hline & MTR & 3.67 & 23.33 & 0.0801 & -7.68 & 0.6674 & 83 \\
\hline & MMM & 5.00 & 10 & 0.0271 & -4.47 & 0.3817 & 63.1 \\
\hline & TTT & 5.00 & 35 & 0.0919 & -7.94 & 0.8193 & 81 \\
\hline & RRR & 5.00 & 16.67 & 0.0563 & -6.27 & 1.269 & 40 \\
\hline \multirow{7}{*}{ Jalenie } & Unsprayed & 45.00 & 99 & 0.157 & -8.69 & 1.04 & 88.6 \\
\hline & RMT & 11.66 & 26.67 & 0.0278 & -3.66 & 0.6375 & 39.2 \\
\hline & TRM & 13.33 & 21.67 & 0.0201 & -3.07 & 0.7168 & 21.1 \\
\hline & MTR & 13.33 & 35 & 0.0399 & -4 & 0.6183 & 58.6 \\
\hline & MMM & 13.33 & 43.33 & 0.0542 & -4.74 & 0.5078 & 79.4 \\
\hline & TTT & 23.33 & 99 & 0.179 & -11.2 & 1.844 & 74.4 \\
\hline & RRR & 8.33 & 11.66 & 0.0083 & -2.93 & 0.74 & 4.1 \\
\hline
\end{tabular}

M = Mancozeb 80 WP, $\mathrm{R}=$ Ridomil Gold MZ 68 WG, T = Trust-Cymocop 439.5 WP applied with the indicated sequence in the three successive sprays

Table4. The effect of alternate fungicide application and potato varieties on late blight proggres rate at Tikur Enchini in the 2017 season

\begin{tabular}{|c|c|c|c|c|c|c|c|c|}
\hline Varieties & Varieties & $\begin{array}{c}\text { Fungicide spray } \\
\text { Sequence }\end{array}$ & DSi & DSf & $\begin{array}{c}\text { Rate } \\
\text { units/day }\end{array}$ & $\begin{array}{c}\text { SE of } \\
\text { intercept }\end{array}$ & $\begin{array}{c}\text { SE of } \\
\text { constant }\end{array}$ & $\mathrm{R} 2$ \\
\hline \multirow{7}{*}{ Belete } & & Unsprayed & 2.33 & 78.33 & 0.142 & -10.8 & 0.4458 & 98 \\
\hline & & RMT & 3.00 & 18.33 & 0.16 & -15.1 & 2.039 & 90.5 \\
\hline & & TRM & 5.67 & 8.33 & 0.0455 & -6.14 & 3.332 & 20.9 \\
\hline & & MTR & 6.00 & 20.00 & 0.108 & -10.7 & 3.158 & 64.6 \\
\hline & & MMM & 6.67 & 46.67 & 0.117 & -10.2 & 1.199 & 88.2 \\
\hline & & TTT & 3.67 & 70.00 & 0.117 & -9.57 & 1.113 & 83.8 \\
\hline & & RRR & 4.00 & 10.00 & 0.0745 & -8.62 & 2.867 & 51.1 \\
\hline \multirow{7}{*}{ Gudenie } & & Unsprayed & 5.00 & 46.67 & 0.0613 & -5.81 & 0.5928 & 77 \\
\hline & & RMT & 5.00 & 8.33 & 0.00696 & -3.14 & 0.4108 & 8.2 \\
\hline & & TRM & 5.00 & 6.67 & 0.00424 & -3.01 & 0.3505 & 4.4 \\
\hline & & MTR & 4.00 & 4.00 & 0.0164 & -3.82 & 0.3742 & 37.4 \\
\hline & & MMM & 4.33 & 4.33 & 0.0204 & -3.94 & 0.2717 & 63.7 \\
\hline & & TTT & 5.00 & 5.00 & 0.0367 & -4.55 & 0.4092 & 71.6 \\
\hline & & RRR & 5.00 & 6.67 & 0.0119 & -3.73 & 0.646 & 20.9 \\
\hline \multirow{7}{*}{ Jalenie } & & Unsprayed & 6.67 & 66.67 & 0.0674 & -5.39 & 0.7967 & 69.1 \\
\hline & & RMT & 5.00 & 26.67 & 0.0366 & -4.16 & 0.6932 & 46.6 \\
\hline & & TRM & 5.00 & 8.33 & 0.0107 & -3.46 & 0.2629 & 34.2 \\
\hline & & MTR & 4.67 & 33.33 & 0.0516 & -5.17 & 0.401 & 83.8 \\
\hline & & MMM & 5.00 & 25.00 & 0.0355 & -4.33 & 0.2929 & 82.1 \\
\hline & & TTT & 5.00 & 50.00 & 0.0606 & -5.43 & 0.3314 & 91.3 \\
\hline & & RRR & 5.00 & 8.33 & 0.00863 & -3.23 & 0.3503 & 15.9 \\
\hline
\end{tabular}

M = Mancozeb 80 WP, $\mathrm{R}=$ Ridomil Gold MZ 68 WG, T = Trust-Cymocop 439.5 WP applied with the indicated sequence in the three successive sprays

\section{CONClusions}

In conclusion, the result of this study showed that, high late blight disease epidemics occurred on unsprayed plots of all the varieties Belete, Gudenie and Jalenie as compared to the best protected plots sprayed with TRM spray sequence. Therefore, production of potatoes in all studied varieties including variety Belete that was previously reported as resistant varieties in other locations should be supplemented with fungicide spray. Alternate fungicide application with TRM spray sequence highly reduced potato late blight epidemics and enhanced the growth and yield parameters of the crop. These are recommended to manage the disease and sustain production.

Moreover, among the three sole fungicide spray sequence three times application of Trust-Cymocop (Cymoxanil $42 \mathrm{~g} / \mathrm{kg}$ + Copperoxychloride $397 \mathrm{~g} / \mathrm{kg}$ at the company recommendation rate $(1.5 \mathrm{~kg} / \mathrm{ha}$ ) was less effective than Mancozeb (Mancozeb 80 WP) and Ridomil Gold (Metalaxyl - 4\%+Mancozeb $-64 \%)$, at the company recommendation rates $(3 \mathrm{~kg} / \mathrm{ha})$. This could be due to the reduce amount of rate to suppress high disease pressure than the other two fungicides for this location. Therefore, further evaluations should be undertaken on the rate determination of the fungicide Trust-Cymocop (Cymoxanil 42g/kg + Copperoxychloride $397 \mathrm{~g} / \mathrm{kg}$ ) for this specific area. 


\section{REFERENCES}

[1] FAOSTAT. 2015. Data base of agricultural production [online]. Available at http://faostat3. fao.org/home/E (updated 31 September 2015; accessed 11 October 2015). Food and Agriculture Organization, Rome, Italy.

[2] Israel Zewide, Ali Mohammed and Solomon Tulu. 2012. Effect of Different Rates of Nitrogen and Phosphorus on Yield and Yield Components of Potato (Solanum tuberosum L.) at Mash District, Southwestern Ethiopia. International Journal of Soil Science, 7: 146-156.

[3] CSA (Central Statistical Agency). 2016. Agricultural sample survey 2015/2016: Report on area and production and farm management practice of belg season crops for private peasant holdings. Vol. V. Statistical Bulletin 532.Central Statistical Agency of Ethiopia (CSA.), Addis Ababa, Ethiopia.

[4] Bekele Kassa and Yaynu Hiskias,1996. Tuber yield loss assessment of potato cultivars with different levels of resistance to late blight. In 3. Annual Conference of the Crop Protection Society of Ethiopia, Addis Abeba (Ethiopia), 149-152 May 1995. CPSE.

[5] Olanya, O.M., Adipala, E., Hakiza, J.J., Kedera, J.C., Ojiambo, P., Mukalazi, J.M., Forbes, G\& Nelson, R. 2001. Epidemiology and population dynamics of Phytophthora infestans in Sub-Saharan Africa: Progress and Constraints. African Crop Science Journal, 9: 181-193.

[6] Forbes, G.A., Grünwald, N.J., Mizubuti, E.S.G., Andrade-Piedra, J.L. and Garrett, K.A., 2014. Potato late blight in developing countries. In: Peters, R.(ed.) Current Concepts in Potato Disease Management. Kerala, India: Research Signpost (In press).

[7] Cooke, L.R., Schepers, H.T.A.M., Hermansen, A., Bain, R.A., Bradshaw, N.J., Ritchie, F., Shaw, D.S., Evenhuis, A., Kessel, G.J.T., Wander, J.G.N. and Andersson, B., 2011. Epidemiology and integrated control of potato late blight in Europe. Potato Research, 54(2), pp.183-222

[8] Schepers, H.T. and Cooke, L.R., 2015. Potato Pathogens in Northern and Western Europe. In Fungicide Resistance in Plant Pathogens (pp. 355-378). Springer, Tokyo.

[9] Goodwin, S.B., Spielman, L.J., Matuszak, J.M., Bergeron, S.N. and Fry, W.E., 1992. Clonal diversity and genetic differentiation of Phytophthora infestans populations in northern and central Mexico. Phytopathology (USA).

[10] MOA (Ministry of Agriculture). 2013. Plant Variety Release, Protection and Seed Quality Control Directorate, Crop Variety Register Issue No.1 6, pp.161-164. , Addis Abeba, Ethiopia.

[11] Wassu Mohammed. 2014. Genetic Variability in Potato (Solanum tuberosum L.) Genotypes for Late blight [Phytophthora infestans (Mont.) de Bary] Resistance and Yield at Haramaya, Eastern Ethiopia. East African Journal of Sciences, 8(1): 13-28.

[12] Shaner, G. and R. Finney, 1977.Inheritance of slow-mildewing resistance in wheat proceedings. American Physiopathology Society, 2: 49 pp.

[13] Henfling, J.W., 1987. Late blight of potato (Vol. 4). International Potato Center.

[14] Gomez, K.A. and Gomez, A.A., 1984. Analysis of data from a series of experiments. Statistical Procedures for Agricultural Research. 2nd ed. New York: J. Wiley, 690pp.

[15] Van der Plank, J.E.1963. Plant Diseases epidemics and control. Academic Press. NewYork. 349. pp.

[16] Berger, R.D., 1981. Comparison of the Gompertz and Logistic Equations to Describe Plant Disease Progress. Phytopathology, 71(7), pp.716-719.

[17] Campbell, C.L. and Madden, L.V.1990. Introduction to Plant Disease Epidemiology. John Wiley and Sons, New York, 532pp.

[18] Fekede Girma. 2011. Management of Late Blight (Phytophthora infestans) of Potato (Solanum tuberosum) through Potato Cultivars and Fungicides in Hararghe Highlands, Ethiopia. M.Sc. Thesis, Haramaya University, Haramaya, Ethiopia.

Citation: Adina Getinet, et.al, "Management of Late Blight [Phytophthora Infestans (Mont.) De Bary] of Potato in Central Ethiopia” International Journal of Research Studies in Agricultural Sciences (IJRSAS), 2019; 5(6), pp. 40-46, http://dx.doi.org/10.20431/2454-6224.0506005

Copyright: (C) 2019 Authors. This is an open-access article distributed under the terms of the Creative Commons Attribution License, which permits unrestricted use, distribution, and reproduction in any medium, provided the original author and source are credited. 